\title{
Assessing willingness to pay for improved sanitation in rural Vietnam
}

\author{
Hoang Van Minh · Hung Nguyen-Viet · \\ Nguyen Hoang Thanh $\cdot$ Jui-Chen Yang
}

Received: 31 July 2012/ Accepted: 17 October 2012/Published online: 10 November 2012

(c) The Japanese Society for Hygiene 2012

\begin{abstract}
Objective The willingness to pay (WTP) for the construction of bathrooms with a flush toilet was assessed in households in a rural community in northern Vietnam. We also examined the effects of socio-economic factors on the WTP.

Methods The contingent valuation method, an economic survey technique, was used. We used the iterative bidding
\end{abstract}

H. Van Minh $(\bowtie)$

Department of Health Economics, Center for Health System Research, Institute for Preventive Medicine and Public Health, Hanoi Medical University, No 1 Ton That Tung,

Dong Da, Hanoi, Vietnam

e-mail: hoangvanminh@hmu.edu.vn

H. Van Minh · N. H. Thanh

Center for Health System Research,

Hanoi Medical University, Hanoi, Vietnam

H. Nguyen-Viet

Center for Public Health and Ecosystem Research (CENPHER),

Hanoi School of Public Health, 138, Giang Vo, Ba Dinh,

Hanoi, Vietnam

H. Nguyen-Viet

Department of Water and Sanitation in Developing Countries

(SANDEC), Swiss Federal Institute of Aquatic Science

and Technology (Eawag), Dübendorf, Switzerland

H. Nguyen-Viet

Department of Epidemiology and Public Health, Swiss Tropical and Public Health Institute (Swiss TPH), Basel, Switzerland

\section{H. Nguyen-Viet}

International Livestock Research Institute (ILRI),

Hanoi, Vietnam

J.-C. Yang

Health Preference Assessment, RTI Health Solutions,

Research Triangle Park, NC, USA game technique to elicit household WTP that involved a sequence of dichotomous choice questions followed by a final open-ended question. A total of 370 households that did not have toilets were selected for this study. Respondents to the questionnaire were the primary income earners and decision-makers of their respective household.

Results Of those responding to the questionnaire, $62.1 \%$ reported being willing to pay for the construction of bathrooms with a flush toilet. The mean and median of maximum WTP amounts were Viet Nam Dong (VND) 15.6 million and VND 13.0 million, respectively (minimum VND 2.0 million; maximum VND 45.0 million). Significant correlates of the WTP rate were: (1) gender of the head of household, (2) age of the head of household, (3) economic status of household, (4) type of current toilet, (5) satisfaction with existing toilet, and (6) knowledge of health effects of poor sanitation. The significant determinants of WTP amount were (1) geographic location and (2) economic status of household.

Conclusion About two-third of the households in the study area were willing to pay for an improvement in their current sanitation arrangements. Both WTP rate and WP amount were strongly influenced by the economic status of the households and health knowledge of the study respondents.

Keywords Contingent valuation - Willingness to pay · Sanitation · Rural · Vietnam

\section{Background}

The World Health Organization (WHO) defines sanitation as a group of methods used to collect human excreta and urine as well as community waste water in a hygienic way, 
where human and community health is not altered [1]. Improved sanitation refers to any method that can hygienically separate human excreta from human contact. Common types of improved sanitation are the flush toilet, septic tank, or pit latrine, a ventilated improved pit latrine (VIP), pit latrine with slab, or composting toilet [2, 3]. Research has shown that improved sanitation brings multiple economic benefits, including those due to the direct economic benefits of not being ill (e.g., economic savings due to lower healthcare expenses), to the indirect economic benefits (e.g., a decrease in lost work days due to illness and a longer lifespan), and (3) to non-health benefits, such as time savings (e.g., time not spent queuing at shared sanitation facilities or walking to a site to defecate in the open) [4-6]. For every U.S. dollar invested, achieving the target of the Millennium Development Goals for sanitation and providing universal sanitation access in non-Organization of Economic and Co-operation Development countries would result in a global return of US\$ 9.1 and US\$ 11.2 , respectively $[4,6]$.

Although many developing countries have no access to improved sanitation [2,7], the governments in these countries cannot afford to provide heavily subsidized improved sanitation to all-or even to the majority-of their respective populations. Consequently, improvements in sanitation situation in these countries heavily rely on the financial contributions from households, which in turn depends on not only each household's willingness to pay (WTP) but also on each household's ability to pay for the improved sanitation services. The WTP concept generally refers to the economic value of a good or service perceived by a person or a household under given conditions. It is essentially the maximum amount of money the beneficiaries are willing to pay for a certain hypothetical service or good [8].

Information on WTP for improved sanitation facilities can be useful to planners at all levels (national, state, city, rural) for assessing the economic viability of projects, setting affordable tariffs, evaluating policy alternatives, assessing financial sustainability, and designing socially equitable subsidies. Such WTP information is also an essential element of a cost-benefit analysis. Net economic benefits of improved sanitation services, in simple terms, are estimated as the difference between the consumers' maximum WTP for better services and the actual cost of the services [9].

Similar to other developing countries, the coverage of improved sanitation in Vietnam remains low. A study by the Ministry of Health on 37,306 households in 224 communes from 48 districts in 20 provinces found that only $18 \%$ of households in rural areas had latrines that met established hygienic standards in terms of construction, operation, and maintenance, including $7.9 \%$ of flush latrines, $7.7 \%$ of septic latrines, $2.0 \%$ double vault latrines, and $0.3 \%$ of biogas latrines. The same study also found that $22.5 \%$ of households had latrines that met established construction standards, including $8.8 \%$ pour flush latrines, $8.6 \%$ septic tanks, $4.8 \%$ double vault latrines, and $0.4 \%$ biogas latrines [10]. Water-borne diseases remain a key issue in Vietnam, with inadequate water supply and sanitation listed as major causes [11]. However, at the time of this study, almost no information on household demand for improved sanitation in Vietnam was available.

To address this information gap in household demand or WTP for improved sanitation in Vietnam, we assessed household WTP for the construction of bathrooms with a flush toilet in a rural community in northern Vietnam and examined the effects of socio-economic factors on the WTP.

\section{Methods}

\section{Contingent valuation method}

We employed the contingent valuation method (CVM) in our study, which is a survey-based economic method in which individuals are asked how much they are willing to pay for a change in quantity or quality (or both) of a particular commodity [12-15]. CVM has been widely used during the last few decades by environmental economists to estimate the benefits of environmental improvements and other public goods $[9,12]$.

Our pilot study revealed that residents of the study area would almost always plan to have a bathroom with a flush toilet rather than a bathroom and a separate room with a flush toilet. We used the iterative bidding game technique to elicit household WTP that involved a sequence of dichotomous choice questions (i.e., yes or no to the option offered in each question) followed by a final open-ended question. The bidding game technique is the most widely used in developing countries [16-18], primarily because it "most closely mimics the normal price taking behavior in local markets" in developing countries [17]. It is also reflects market realism more than a single open-ended question [14, 19] and is more reliable than a single dichotomous choice question [20].

In the bidding game, we set the price for a common type of bathroom with a flush toilet at Viet Nam Dong (VND) 20 million (around US\$1000), which was higher than the actual cost of building one such bathroom. Based on the interviews with local engineers/constructors during our pilot study, a common type of bathroom with a flush toilet would cost around VND 12 million to VND 15 million (US\$ 600-750) to build. 
Q1. The cost of constructing a bathroom with a flush toilet is VND 20 million, are you willing to pay that amount?

Yes $=>Q 2 ;$ No $=>Q 4 ;$ Don't know $=>Q 6$.

Q2. What if the cost is VND 25 million, will you be willing to pay?

Yes $=>Q 3 ;$ No $=>$ Stop; Don't know $=>Q 6$.

Q3. What if the cost is VND 30 million, will you be willing to pay?

Yes $=>Q 6 ;$ No $=>$ Stop; Don't know $=>Q 6$.

Q4. What if the cost is VND 15 million, will you be willing to pay?

Yes $=>Q 6 ;$ No $=>Q 5 ;$ Don't know $=>Q 6$.

Q5. What if the cost is VND 10 million, will you be willing to pay?

Yes $=>$ Stop; No $=>Q 6 ;$ Don't know $=>Q 6$.

Q6. What really is the maximum amount you are willing to pay for the construction of a flush toilet in a bathroom.

Study area

The study was conducted in March and July 2011, in the Kim Bang district of Ha Nam province, which is $60 \mathrm{~km}$ south of Vietnam's capital, Hanoi. Kim Bang district was chosen because it is considered to be representative of a typical rural community in northern Vietnam. Two communes were selected for this study, including Hoang Tay and Nhat Tan. Compared to Nhat Tan, Hoang Tay is relatively less well-off socio-economically. According to local statistics, the per capita monthly income in Nhat Tan and Hoang Tay in 2010 was around US\$ 65 and US\$ 35, respectively. This study protocol was approved by the ethical and scientific review board of Hanoi Medical University.

Study respondents, sample size, and sampling

The primary income earners and decision-makers of those households which did not have a bathroom with a flush toilet at the time of the study were considered to be the respondents in this study. The minimum sample size was estimated to be 171 households for each selected commune with an anticipated proportion of households who would be willing to pay for the interested service (bathroom with flush toilet) of $50 \%$, level of significance of $5 \%$, and relative error of $20 \%$. To control for non-response rate (expected to be $10 \%$ ), we planned to interview 188 households in each commune ( 376 households in the two communes). In each selected study commune, the sample was randomly selected from the list of households with no flush toilet (2442 households in Hoang Tay and 4931 households in Nhat Tan). All respondents acknowledged they have provided documented informed consent.

Study questionnaire

The study questionnaire was drafted by the research team after a field visit during the preparation phase. During the preparation phase, the research team met with key stakeholders in both communes and had two focus group discussions with locals from these communes. The questionnaire was then modified based on the findings of a set of cognitive interviews with about 10-15 local people representative of gender, age, education, occupation and economic status of the residents. The questionnaire was finalized after being field-tested with 30 local respondents.

The final questionnaire contained five sections:

(1) An introductory section in which the study background and purpose of the survey was described.

(2) Questions on current water and sanitation conditions and satisfaction (or not) with the current sanitation arrangements.

(3) Contingent valuation scenario consisting of descriptions of the bathroom with a flush toilet and possible benefits of having such a bathroom followed by a battery of questions eliciting WTP. All enumerators were instructed to read the constructed contingent valuation scenario to all interviewees exactly the way it was written, and enumerators then asked the WTP questions.

(4) Questions on socio-economic status of the interviewee and his/her household, including gender, age, education, occupation, economic status (the economic status of a household was described as poor and nonpoor, as identified by the Commune People Committee based on the criteria of the Ministry of Labor, Invalids and Society), household size, having children under 6 years of age in the household, having elderly people in the household, as well as knowledge of health effects due to poor sanitation.

(5) Debriefing questions.

Overall, the study questionnaire was relatively straightforward to conduct, and, on average, it took about 20 min to administer.

Data collection and supervision

Ten enumerators, all students with a Bachelor's degree in Public Health from Hanoi Medical University, were selected 
and trained for the data collection task in a 5-day workshop that included a briefing on the study objectives and training on how to use the draft questionnaire. The work-shop consisted of a lecture, mock interviews, and actual field practice. After field-testing the questionnaire, the research team, and the enumerators revised the questionnaire based on the findings from the pretest interviews. All interviews were conducted in person.

Data management and analysis

Data recorded on the paper questionnaires were entered into a computer using the EpiData data management software. Both descriptive and analytical statistics were carried out using Stata ver. 10 (Stata Corp, College Station, TX). A logistic regression model was built to estimate the probability of being willing to pay for construction of a bathroom with a toilet (WTP rate) based on socio-economic factors (such as area, gender, age, education, occupation of the head of household, household size, having children under the age of 6 years in the household, having elderly people in the household, main source of water, current toilet, economic status,), satisfaction with the current toilet, knowledge of health effects due to poor sanitation [i.e., people who could only name fewer than three diseases caused by poor sanitation conditions were considered (for the purposes of this study) to have a poor knowledge of the health effects of poor sanitation], and having a family member with a chronic disease (he or she had been told by a health worker that they had chronic joint problems, heart and circulatory conditions, cancer, diabetes, chronic pulmonary diseases, or psychological illness). The log-linear regression model (the dependent variable was transformed to logarithms) was applied to identify socio-economic factors that would influence household WTP amount. Twotailed tests were considered to be significant at 0.05 . Values in the Viet Nam Dong were converted into U.S. dollars using the 2011 exchange rates: US\$ $1=$ VND 20000.

\section{Results}

General description of the study respondents

A total of 370 households participated in this study. Demographic and socio-economic characteristics of the study respondents are described in Table 1 . In both communes, there were more men than women. The highest proportion of respondents fell into the 45- to 54-year age group. A majority of the study respondents had either primary or secondary education. Most households comprised fewer than five people. The proportion of interviewees who worked as a farmer was higher in Nhat Tan $(79.5 \%)$ than in
Table 1 General characteristics of the study sample

\begin{tabular}{lcll}
\hline Characteristics & $\begin{array}{l}\text { Hoang Tay, } \\
n(\%)\end{array}$ & $\begin{array}{l}\text { Nhat Tan, } \\
n(\%)\end{array}$ & $\begin{array}{l}\text { Both communes, } \\
n(\%)\end{array}$ \\
\hline $\begin{array}{l}\text { Overall } \\
\text { Gender of the head of household }\end{array}$ & $180(100)$ & $370(100)$ \\
Male & $79(41.6)$ & $81(45.0)$ & $160(43.2)$ \\
Female & $111(58.4)$ & $99(55.0)$ & $210(56.8)$ \\
Age of the head of household (years) & & \\
$<24$ & $6(3.2)$ & $14(7.8)$ & $20(5.4)$ \\
$25-34$ & $36(18.9)$ & $40(22.2)$ & $76(20.5)$ \\
$35-44$ & $39(20.5)$ & $36(20.0)$ & $75(20.3)$ \\
$45-54$ & $60(31.6)$ & $51(28.3)$ & $111(30.0)$ \\
$55-64$ & $30(15.8)$ & $29(16.1)$ & $59(15.9)$ \\
$65+$ & $19(10.0)$ & $10(5.6)$ & $29(7.8)$
\end{tabular}

Education of the head of household

$\begin{array}{lccc}\text { Primary } & 79(41.6) & 102(56.7) & 181(48.9) \\ \text { Secondary } & 95(50.0) & 67(37.2) & 162(43.8) \\ \text { Tertiary and higher } & 16(8.4) & 11(6.1) & 27(7.3) \\ \text { Occupation of the head of household } & & \\ \text { Farmer } & 151(79.5) & 107(59.4) & 258(69.7) \\ \text { Non-farmer } & 39(20.5) & 73(40.6) & 112(30.3) \\ \text { Household size } & & & \\ <5 \text { members } & 151(70.5) & 130(72.2) & 281(75.9) \\ \geq 5 \text { members } & 39(20.5) & 50(27.8) & 89(24.1)\end{array}$

Having children aged $<6$ years

$\begin{array}{lrrr}\text { Yes } & 33(17.4) & 45(25.0) & 78(21.1) \\ \text { No } & 157(82.6) & 135(75.0) & 292(78.9)\end{array}$

Having people aged $\geq 60$ years

$\begin{array}{lrrr}\text { Yes } & 63(33.2) & 42(23.3) & 105(28.4) \\ \text { No } & 127(66.8) & 138(76.7) & 265(71.6)\end{array}$

Main sources of water

$\begin{array}{lccc}\text { Tap water } & 1(0.5) & 18(10.0) & 19(5.1) \\ \text { Rain, well water } & 189(99.5) & 162(90.0) & 351(94.9) \\ \text { Current toilet } & & & \\ \text { Double vault toilet } & 41(21.6) & 16(8.9) & 57(15.4) \\ \text { Single vault toilet } & 128(67.4) & 155(86.1) & 283(76.5) \\ \text { No toilet } & 21(11.0) & 9(5.0) & 30(8.1) \\ \text { Dissatisfaction with the current toilet } & & \\ \text { Yes } & 159(83.7) & 138(76.7) & 297(80.3) \\ \text { No } & 31(16.3) & 42(23.3) & 73(19.7) \\ \text { Economic status of household } & & \\ \text { Poor } & 30(15.8) & 12(6.7) & 42(11.4) \\ \text { Non-poor } & 160(84.2) & 168(93.3) & 328(88.6)\end{array}$

Knowledge of health impacts of poor sanitation

\begin{tabular}{lcrr} 
Poor & $185(97.4)$ & $145(80.6)$ & $330(89.2)$ \\
Better & $5(2.6)$ & $35(19.4)$ & $40(10.8)$ \\
\hline
\end{tabular}

Hoang Tay (59.4\%). While only one household in Hoang Tay had tap water, $10.0 \%$ of the households in Nhat Tan had tap water. Hoang Tay had more households without a 
toilet $(11.0 \%)$ than Nhat Tan $(5 \%)$. The percentage of poor households in Hoang Tay and Nhat Tan was 15.8 and $6.7 \%$, respectively.

Willingness to pay for the construction of bathroom with flush toilet

Table 2 presents the pattern of WTP for the construction of a bathroom with a flush toilet in the study area. Overall, the proportion of respondents who reported being willing to pay for the interest service (who answered yes to one of the six bid questions) was $62.1 \%$. There was no statistically significant difference in the WTP rates by commune, education and occupation of the head of households, household size, and the type of main sources of water. However, the WTP rates were significantly different by (1) gender of the household head (men were more willing to pay than women), (2) age of the household head (the WTP rate was lowest among the oldest age groups), (3) economic status of the household (the non-poor households were more willing to pay than the poor), (4) type of the toilet currently using (households with double vault toilet were more willing to pay than those had single vault toilet or no toilet), (5) dissatisfaction with existing toilet (respondents who were dissatisfied with the current toilet were more willing to pay), and (6) knowledge of health effects due to poor sanitation (people with better knowledge of health effects of poor sanitation were more willing to pay).

Table 3 reports the mean and median of maximum WTP amounts for the construction of a bathroom with a flush toilet reported by the study respondents (i.e., among those who were willing to pay). Overall, the mean and median of the maximum WTP amounts were VND 15.6 million and VND 13.0 million, respectively (minimum VND 2.0 million; maximum VND 45.0 million). The levels of maximum WTP were significantly different by (1) geographic location (Nhat Tan had higher WTP amount), (2) age of the head of household (people aged $\geq 65$ years bod the lowest WTP amount), (3) occupation (lower WTP amount was found for farmers), and (4) economic status (the non-poor households were willing to pay higher amounts than the poor households).

Multiple logistic regression analysis of socio-economic correlates of WTP for the construction of a bathroom with a flush toilet is shown in Table 4. After controlling for other variables, the significant correlates of the WTP rate were found to be: (1) gender of the head of household (men were more willing to pay than women), (2) age of the head of household (WTP rate was lowest among the oldest age groups), (3) type of current toilet (households with single
Table 2 The pattern of willingness to pay (WTP) for the construction of a bathroom with a flush toilet $(N=370)$

\begin{tabular}{|c|c|c|}
\hline Characteristics & $n(\%)^{\mathrm{a}}$ & $p$ (chi-squared test) \\
\hline Overall & $230(62.1)$ & \\
\hline \multicolumn{3}{|l|}{ Area } \\
\hline Hoang Tay & $116(61.1)$ & \multirow[t]{2}{*}{0.65} \\
\hline Nhat Tan & $114(63.3)$ & \\
\hline \multicolumn{3}{|c|}{ Gender of the head of household } \\
\hline Male & $110(68.8)$ & \multirow[t]{2}{*}{$0.02 *$} \\
\hline Female & $120(57.1)$ & \\
\hline \multicolumn{3}{|c|}{ Age of the head of household (years) } \\
\hline$<24$ & $14(70.0)$ & \multirow[t]{6}{*}{$0.003 *$} \\
\hline $25-34$ & $56(73.7)$ & \\
\hline $35-44$ & $50(66.7)$ & \\
\hline $45-54$ & $71(63.9)$ & \\
\hline $55-64$ & $28(47.5)$ & \\
\hline $65+$ & $11(37.9)$ & \\
\hline \multicolumn{3}{|c|}{ Education of the head of household } \\
\hline Primary & $107(59.1)$ & \multirow[t]{3}{*}{0.27} \\
\hline Secondary & $108(66.7)$ & \\
\hline Tertiary and higher & $15(55.6)$ & \\
\hline \multicolumn{3}{|c|}{ Occupation of the head of household } \\
\hline Farmer & $156(60.5)$ & \multirow[t]{2}{*}{0.31} \\
\hline Non-farmer & $74(66.1)$ & \\
\hline \multicolumn{3}{|l|}{ Household size } \\
\hline$<5$ members & $174(61.9)$ & \multirow[t]{2}{*}{0.87} \\
\hline$\geq 5$ members & $56(62.9)$ & \\
\hline \multicolumn{3}{|c|}{ Having children aged $<6$ years } \\
\hline Yes & $53(67.9)$ & \multirow[t]{2}{*}{0.24} \\
\hline No & $177(60.6)$ & \\
\hline \multicolumn{3}{|c|}{ Having people aged $\geq 60$ years } \\
\hline Yes & $48(45.7)$ & \multirow[t]{2}{*}{$<0.001^{*}$} \\
\hline No & $182(68.7)$ & \\
\hline \multicolumn{3}{|l|}{ Main sources of water } \\
\hline Tape water & $15(78.9)$ & \multirow[t]{2}{*}{0.12} \\
\hline Rain, well water & $215(61.3)$ & \\
\hline \multicolumn{3}{|l|}{ Current toilet } \\
\hline Double vault toilet & $47(82.5)$ & \multirow[t]{3}{*}{$0.001 *$} \\
\hline Single vault toilet & $170(60.1)$ & \\
\hline No toilet & $13(43.3)$ & \\
\hline \multicolumn{3}{|c|}{ Dissatisfaction with the current toilet } \\
\hline Yes & $198(66.7)$ & \multirow[t]{2}{*}{$<0.001^{*}$} \\
\hline No & $32(43.8)$ & \\
\hline \multicolumn{3}{|c|}{ Economic status of household } \\
\hline Poor & $15(35.7)$ & \multirow[t]{2}{*}{$<0.001^{*}$} \\
\hline Non-poor & $215(65.6)$ & \\
\hline Knowledge of health & poor sanitat & \\
\hline Poor & $196(59.4)$ & $0.002 *$ \\
\hline Better & $34(85.0)$ & \\
\hline
\end{tabular}

* Significant at $P \leq 0.05$

${ }^{\text {a }}$ Percentages in proportion to the overall respondents 
Table 3 Levels of maximum WTP for the construction of a bathroom with flush toilet (among those who were willing to pay)

\begin{tabular}{|c|c|c|c|c|}
\hline Characteristics & $\begin{array}{l}\text { Mean of maximum WTP } \\
\text { amount }^{\mathrm{a}}\end{array}$ & $\begin{array}{l}\text { Median of maximum WTP } \\
\text { amount }^{\mathrm{a}}\end{array}$ & $\begin{array}{l}\text { Interquartile range of WTP } \\
\text { amount }^{\mathrm{a}}\end{array}$ & $\begin{array}{l}p \text { value (non-parametric } \\
\text { test }^{\mathrm{b}}\end{array}$ \\
\hline Overall & 15613 & 13000 & $8000-22000$ & - \\
\hline \multicolumn{5}{|l|}{ Area } \\
\hline Hoang Tay & 13543 & 10000 & $5000-20000$ & \multirow{2}{*}{$0.006^{*}$} \\
\hline Nhat Tan & 17719 & 18000 & $10000-25000$ & \\
\hline \multicolumn{5}{|c|}{ Gender of the head of household } \\
\hline Male & 15527 & 12000 & $7000-20000$ & \multirow[t]{2}{*}{0.84} \\
\hline Female & 15691 & 15000 & $8000-23000$ & \\
\hline \multicolumn{5}{|c|}{ Age of the head of household (years) } \\
\hline$<24$ & 15071 & 13000 & $11000-15000$ & \multirow[t]{6}{*}{$0.003 *$} \\
\hline $25-34$ & 19678 & 20000 & $10000-29000$ & \\
\hline $35-44$ & 15080 & 10000 & $7000-20000$ & \\
\hline $45-54$ & 15471 & 15000 & $6000-20000$ & \\
\hline $55-64$ & 12303 & 9500 & $5000-18500$ & \\
\hline $65+$ & 7363 & 10000 & $2000-12000$ & \\
\hline \multicolumn{5}{|c|}{ Education of the head of household } \\
\hline Primary & 16023 & 15000 & $8000-25000$ & \multirow[t]{3}{*}{0.17} \\
\hline Secondary & 14634 & 11000 & $8000-20000$ & \\
\hline Tertiary and higher & 19733 & 20000 & $12000-30000$ & \\
\hline \multicolumn{5}{|c|}{ Occupation of the head of household } \\
\hline Farmer & 14192 & 10000 & $6000-20000$ & \multirow[t]{2}{*}{$0.007 *$} \\
\hline Non-farmer & 18608 & 19000 & $10000-25000$ & \\
\hline \multicolumn{5}{|l|}{ Household size } \\
\hline$<5$ members & 16069 & 14500 & $8000-25000$ & \multirow[t]{2}{*}{0.34} \\
\hline$\geq 5$ members & 14196 & 10500 & $7000-20000$ & \\
\hline \multicolumn{5}{|c|}{ Having children aged $<6$ years } \\
\hline Yes & 17443 & 20000 & $8000-25000$ & \multirow[t]{2}{*}{0.08} \\
\hline No & 15065 & 12000 & $8000-20000$ & \\
\hline \multicolumn{5}{|c|}{ Having people aged $\geq 60$ years } \\
\hline Yes & 13364 & 10000 & $8000-25000$ & \multirow[t]{2}{*}{0.07} \\
\hline No & 16206 & 15000 & $7000-20000$ & \\
\hline \multicolumn{5}{|l|}{ Main sources of water } \\
\hline Tap water & 17866 & 20000 & $5000-30000$ & \multirow[t]{2}{*}{0.50} \\
\hline Rain, well water & 15455 & 13000 & $8000-20000$ & \\
\hline \multicolumn{5}{|l|}{ Current toilet } \\
\hline Double vault toilet & 14787 & 10000 & $8000-20000$ & \multirow[t]{3}{*}{0.74} \\
\hline Single vault toilet & 15805 & 15000 & $8000-23000$ & \\
\hline No toilet & 16076 & 12000 & $5000-30000$ & \\
\hline \multicolumn{5}{|c|}{ Dissatisfaction with the current toilet } \\
\hline Yes & 15757 & 13500 & $10000-17500$ & \multirow[t]{2}{*}{0.85} \\
\hline No & 14718 & 12500 & $7000-25000$ & \\
\hline \multicolumn{5}{|c|}{ Economic status of household } \\
\hline Poor & 6300 & 5000 & $3000-10000$ & $<0.001 *$ \\
\hline Non-poor & 16262 & 15000 & $9000-25000$ & \\
\hline Knowledge of health & $\mathrm{s}$ of poor sanitation & & & \\
\hline Poor & 15413 & 13000 & $8000-20000$ & 0.63 \\
\hline Better & 16764 & 13500 & $6000-27000$ & \\
\hline
\end{tabular}

* Significant at $P \leq 0.05$

${ }^{a}$ Values are given in Viet Nam Dong (VND) and represent the number of million VND

b The Mann-Whitney $U$ test for comparing two groups and the Kruskal-Wallis for comparing more than two groups based on their sum of ranks 
Table 4 Multiple logistic regression analyses of determinants of willingness to pay

\begin{tabular}{|c|c|c|}
\hline Characteristics & Odds ratio & $95 \% \mathrm{CI}$ \\
\hline \multicolumn{3}{|l|}{ Area } \\
\hline Hoang Tay & Reference & - \\
\hline Nhat Tan & 0.70 & $0.40-1.22$ \\
\hline \multicolumn{3}{|c|}{ Gender of the head of household } \\
\hline Male & Reference & - \\
\hline Female & 0.40 & $0.24-0.68^{*}$ \\
\hline \multicolumn{3}{|c|}{ Age of the head of household (years) } \\
\hline$<24$ & Reference & - \\
\hline $25-34$ & 0.53 & $0.15-1.86$ \\
\hline $35-44$ & 0.43 & $0.12-1.51$ \\
\hline $45-54$ & 0.29 & $0.08-1.02$ \\
\hline $55-64$ & 0.21 & $0.06-0.80 *$ \\
\hline $65+$ & 0.11 & $0.02-0.53^{*}$ \\
\hline \multicolumn{3}{|c|}{ Education of the head of household } \\
\hline Primary & Reference & - \\
\hline Secondary & 1.03 & $0.61-1.74$ \\
\hline Tertiary and higher & 0.60 & $0.22-1.59$ \\
\hline \multicolumn{3}{|c|}{ Occupation of the head of household } \\
\hline Farmer & Reference & - \\
\hline Non-farmer & 1.16 & $0.63-2.14$ \\
\hline \multicolumn{3}{|l|}{ Household size } \\
\hline$<5$ members & Reference & - \\
\hline$\geq 5$ members & 1.08 & $0.58-2.00$ \\
\hline \multicolumn{3}{|c|}{ Having children aged $<6$ years } \\
\hline Yes & 0.94 & $0.47-1.86$ \\
\hline No & Reference & - \\
\hline \multicolumn{3}{|c|}{ Having people aged $\geq 60$ years } \\
\hline Yes & 0.44 & $0.24-0.79$ \\
\hline No & Reference & - \\
\hline \multicolumn{3}{|l|}{ Main sources of water } \\
\hline Tap water & Reference & Reference \\
\hline Rain, well water & 0.34 & $0.93-1.44$ \\
\hline \multicolumn{3}{|l|}{ Current toilet } \\
\hline Double vault toilet & Reference & - \\
\hline Single vault toilet & 0.24 & $0.11-0.54 *$ \\
\hline No toilet & 0.12 & $0.04-0.37 *$ \\
\hline \multicolumn{3}{|c|}{ Dissatisfaction with the current toilet } \\
\hline Yes & 2.84 & $1.51-5.33^{*}$ \\
\hline No & Reference & - \\
\hline \multicolumn{3}{|c|}{ Economic status of household } \\
\hline Poor & 0.40 & $0.18-0.91 *$ \\
\hline Non-poor & Reference & - \\
\hline \multicolumn{3}{|c|}{ Having a family member with a chronic disease } \\
\hline Yes & 1.30 & $0.79-2.18$ \\
\hline No & Reference & - \\
\hline \multicolumn{3}{|c|}{ Knowledge of health impacts of poor sanitation } \\
\hline Poor & Reference & - \\
\hline Better & 3.94 & $1.45-10.71 *$ \\
\hline
\end{tabular}

$95 \%$ CI $95 \%$ confidence interval

* Significant at $P \leq 0.05$ (95\% CI does not include 1) vault toilet or without toilet were less willing to pay), (4) satisfaction with existing toilet (respondents who were dissatisfied with the current toilet were more willing to pay), (5) economic status of household (the poor households were less willing to pay than the non-poor), and (6) knowledge of health effects of poor sanitation (people with a better knowledge of the health effects of poor sanitation were more willing to pay).

Table 5 shows the results of the multiple log-linear regression analysis of determinants of levels of WTP for construction of bathroom with flush toilet (among those who were willing to pay). After controlling for other variables, the significant determinants of WTP amount were (1) geographic location (people in the Nhat Tan were wiling to pay higher amount), and (2) economic status of household (The non-poor households were willing to pay higher amount).

\section{Discussion}

Very few studies of the kind we report here have been conducted in Vietnam, and our results therefore provide valuable insight into the household demand for improved sanitation in rural Vietnam. Household demand for a good or service is usually measured by estimating a household's WTP for that good or service $[9,16]$. A household is willing to pay for an improved sanitation service not only for its direct use values but also for the associated benefits, such as reducing illnesses, enhancing social status, and improving the cleanness of the ambient environment [21]. The evidence generated from this study is expected to be used for designing policies for public health as well as sanitation projects in the study area and elsewhere.

We found that about $62 \%$ of the households in the study area were interested in constructing a new bathroom with a flush toilet. This was greater than the $31 \%$ reported from a 2006 study in rural and peri-urban areas in Ghana [22] but less than the $80 \%$ found by a 2008 study in rural Bangladesh [23]. The mean WTP was about VND 15.6 million (about US\$ 780), which was about $30 \%$ of the disposable annual household income. This value was higher than the actual cost of a common type of bathroom with a flush toilet offered in the study area (ranging from VND 12-15 million or US\$ $600-750)^{1}$. The proportions of households that were willing to pay more than VND 12 million and more than VND 15 million were 69.2 and $63.5 \%$. These findings suggest that households in the study area were willing to pay for an improvement in their current sanitation arrangements and, with some subsidies, it might be

\footnotetext{
${ }^{1}$ Revealed from the interviews with local engineers/constructors during our pilot study.
} 
Table 5 Log linear regression modeling for determinants of willingness to pay level

\begin{tabular}{|c|c|c|c|}
\hline Characteristics & Coefficient & $p$ & $95 \% \mathrm{CI}$ \\
\hline \multicolumn{4}{|l|}{ Area } \\
\hline Hoang Tay & Reference & - & - \\
\hline Nhat Tan & 0.32 & $0.005^{*}$ & $0.11-0.54 *$ \\
\hline \multicolumn{4}{|c|}{ Gender of the head of household } \\
\hline Male & Reference & - & - \\
\hline Female & -0.06 & 0.51 & -0.26 to 0.13 \\
\hline \multicolumn{4}{|c|}{ Age of the head of household (years) } \\
\hline$<24$ & Reference & - & - \\
\hline $25-34$ & 0.46 & 0.05 & $0.00-0.91$ \\
\hline $35-44$ & 0.20 & 0.41 & -0.28 to 0.68 \\
\hline $45-54$ & 0.22 & 0.37 & -0.26 to 0.69 \\
\hline $55-64$ & 0.07 & 0.79 & -0.45 to 0.60 \\
\hline $65+$ & -0.51 & 0.12 & -1.15 to 0.13 \\
\hline \multicolumn{4}{|c|}{ Education of the head of household } \\
\hline Primary & Reference & - & - \\
\hline Secondary & -0.07 & 0.46 & -0.27 to 0.12 \\
\hline Tertiary and higher & -0.02 & 0.92 & -0.42 to 0.38 \\
\hline \multicolumn{4}{|c|}{ Occupation of the head of household } \\
\hline Farmer & Reference & - & - \\
\hline Non-farmer & 0.18 & 0.11 & -0.04 to 0.4 \\
\hline \multicolumn{4}{|l|}{ Household size } \\
\hline$<5$ members & Reference & - & - \\
\hline$\geq 5$ members & -0.20 & 0.10 & -0.43 to 0.04 \\
\hline \multicolumn{4}{|c|}{ Having children aged $<6$ years } \\
\hline Yes & 0.11 & 0.38 & -0.13 to 0.35 \\
\hline No & Reference & - & - \\
\hline \multicolumn{4}{|c|}{ Having people aged $\geq 60$ years } \\
\hline Yes & -0.04 & 0.76 & -0.29 to 0.21 \\
\hline No & Reference & - & - \\
\hline \multicolumn{4}{|l|}{ Main sources of water } \\
\hline Tape water & Reference & - & - \\
\hline Rain, well water & 0.07 & 0.74 & -0.32 to 0.45 \\
\hline \multicolumn{4}{|l|}{ Current toilet } \\
\hline Double vault toilet & Reference & - & - \\
\hline Single vault toilet & -0.24 & 0.05 & -0.49 to 0 \\
\hline No toilet & -0.12 & 0.59 & -0.57 to 0.33 \\
\hline \multicolumn{4}{|c|}{ Dissatisfaction with the current toilet } \\
\hline Yes & 0.03 & 0.84 & -0.26 to 0.32 \\
\hline No & Reference & - & - \\
\hline \multicolumn{4}{|c|}{ Economic status of household } \\
\hline Poor & -0.83 & $<0.001 *$ & -1.22 to $-0.43^{*}$ \\
\hline Non-poor & Reference & - & - \\
\hline \multicolumn{4}{|c|}{ Having a family member with a chronic disease } \\
\hline Yes & -0.10 & 0.34 & -0.3 to 0.11 \\
\hline No & Reference & - & - \\
\hline \multicolumn{4}{|c|}{ Knowledge of health impacts of poor sanitation } \\
\hline Poor & Reference & - & - \\
\hline Better & 0.17 & 0.23 & -0.44 to 0.11 \\
\hline Constant & 8.94 & $<0.001 *$ & 7.75-10.13* \\
\hline
\end{tabular}

* Significant at $P \leq 0.05$ possible to achieve the target of $75 \%$ improved sanitation coverage in 2015 that was set by the Vietnam National Program on Water and Sanitation in the study area [24].

A secondary aim of our study was to gain an understanding of how demographic and socio-economic characteristics would affect the WTP for improved sanitation. We found a negative relationship between female respondents and the WTP rate, which implies that women in the study area appeared to be less concerned about sanitation. The WTP rate was lower among aged people, possibly because as people get older, they tend to be more "economically" conservative and their WTP decreases.

We found that both WTP rate and WTP amount were strongly influenced by the economic status of households. This finding is in line with our hypothesis that poorer households (with lower income) should have a lower demand for all goods in general, including improved sanitation, due to income constraints. Similar findings were also reported in studies from Ghana [12] and Peru [13]. The lower WTP among the poor would result in this vulnerable group having a lower chance to gain access to improved sanitation. Also, poor sanitation has been shown to be a key link between disease and poverty [25], and it is very important to break the cycle. If a bathroom with a flush toilet were to be a luxury for the poor, it might be important to offer other service options in terms of quality and associated tariffs to better match their needs and ability to pay. At the same time, polices/interventions, such as subsidies from the government, low-interest loans, and microfinance schemes, might be necessary to improve the access of poor households to improved sanitation conditions.

Our findings also show that people with better health literacy were more willing to pay for the improved sanitation service. In fact, the more people understand the consequences of using unimproved sanitation, the more likely they are willing to pay for the service. Our findings also resonate with those found in studies from Peru [13], Ghana [22], and Bangladesh [23]. As the level of knowledge on the health impacts of sanitation is still limited among local rural people, health education, including extensive sanitation modules, is urgently needed in this setting.

Our study results also confirm that the primary motivation to improve current sanitation arrangements arises from dissatisfaction with existing sanitation options $[12,26]$.

We need to note some methodological issues associated with the use of the CVM in this study. Eliciting consumer preferences through in-person interviews was not an easy task, and several potential biases might be introduced because of the way the study sample was selected, the 
questions were framed, the CVM scenario was structured, the elicitation method was used, and the survey was conducted [12, 16, 27-29]. Thus, to ensure the validity and reliability of the CVM findings, we followed the guidelines developed by Gunatilake et al. [29] on methods for conducting a study on WTP for water and sanitation services in developing countries. We conducted several field visits to develop appropriate CVM scenarios and questions. We also implemented a number of cognitive interviews with the local people to ensure the CVM scenarios and questions were easy to understand. Careful training of enumerators and field-testing also helped to ensure the validity and reliability of the study findings.

We used the iterative bidding game technique because this format has been the most widely used methodology for such studies in developing countries [16-18] and is regarded as the one that "most closely mimics the normal price taking behavior in local markets" in developing countries [17]. The bidding game was found to have more market realism than a single open-ended question $[14,19]$ and to be more reliable than a single dichotomous choice question [20]. An important disadvantage of the bidding game is the threat of starting-point bias, where the respondent's final WTP value is not independent of the first bid prompted by the interviewer [16, 30]. Our pilot study revealed that, compared to the single open-ended question and the single dichotomous choice format, the iterative bidding game technique did get respondents more involved in the bid and gave them more time to think and respond to the WTP questions.

In conclusion, we found that about two-thirds of households in the study area were willing to pay for an improvement in their current sanitation arrangements. Both WTP rate and WP amount were strongly influenced by the economic status of households and health knowledge of the study respondents.

Acknowledgments This work has been supported by the Swiss National Science Foundation (SNSF) and the Swiss Agency for Development and Cooperation (SCD) through the program of the National Center for Competences in Research (NCCR) North-South.

Conflict of interest None.

\section{References}

1. World Health Organization. Technology for water supply and sanitation in developing countries. Geneva: World Health Organization; 1987.

2. World Health Organization. UNICEF: Progress on sanitation and drinking-water-2010 update. Geneva: World Health Organization; 2010.

3. Hutton G, Haller L. Evaluation of the costs and benefits of water and sanitation improvement at the global level. Geneva: World Health Organization; 2004.
4. Hutton G, Haller L, Bartram J. Global costs-benefit analysis of water supply and sanitation interventions. J Water Health. 2007;5(4):481-502.

5. Haller L, Hutton G, Bartram J. Estimating the costs and health benefits of water and sanitation improvements at global level. J Water Health. 2007;5(4):467-80.

6. Hutton G, Haller L, Bartram J. Economic and health effects of increasing coverage of low-cost household drinking-water supply and sanitation interventions to countries off-track to meet MDG target 10. Geneva: World Health Organization; 2007.

7. Mara D, Lane J, Scott B, Trouba D. Sanitation and Health. PLoS Med. 2010;7(11):e1000363.

8. Russell S, Fox-Rushby J, Arhin D. Willingness and ability to pay for health care: a selection of methods and issues. Health Policy Plan. 1995;10(1):94-101.

9. Gunatilake H, Yang JC, Pattanayak S, van der Berg C. Willingness to pay and design of water supply and sanitation projects: a case study (ERD Technical Note Series No. 19). Manila: Asian Development Bank; 2006.

10. Ministry of Health of Vietnam. The survey on environmental sanitation in rural Vietnam. Hanoi: Ministry of Health of Vietnam; 2006.

11. Thang P, Tuan H, Hutton G. Economic impacts of sanitation in Vietnam. Hanoi: World Bank; 2008.

12. Whittington D, Lauria DT, Wright AM, Choe K, Hughes JA, Swarna V. Household demand for improved sanitation services in Kumasi, Ghana: a contingent valuation study. Water Resour Res. 1993;29(6):1539-60.

13. Fujita Y, Fujii A, Furukawa S, Ogawa T. Estimation of willingness-to-pay (WTP) for water, sanitation services through contingent valuation (CVM) method, a case study in Iquitos City, the Republic of Peru. Iquitos: Japan Bank for International Cooperation; 2005.

14. O'Brien B, Viramontes JL. Willingness to pay: a valid and reliable measure of health state preference? Med Decis Making. 1994;14(3):289-97.

15. Frew EJ, Wolstenholme JL, Whynes DK. Comparing willingness-to-pay: bidding game format versus open-ended and payment scale formats. Health Policy. 2004;68(3):289-98.

16. Whittington D. Administering contingent valuation surveys in developing countries. World Dev. 1998;26(1):21-30.

17. Onwujekwe $O$, Nwagbo D. Investigating starting-point bias: a survey of willingness to pay for insecticide-treated nets. Soc Sci Med. 2002;55(12):2121-30.

18. Milanesi J. Measuring demand for sanitation in developing countries: a new theoretical and methodological framework for contingent valuation surveys. In: 12th Conf Association for Heterodox Economics. Bordeaux; 2010.

19. Frew EJ, Wolstenholme JL, Whynes DK. Comparing willingness-to-pay: bidding game format versus open-ended and payment scale formats. Health Policy. 2004;68(3):289-98.

20. Dong H, Kouyate B, Cairns J, Sauerborn R. A comparison of the reliability of the take-it-or-leave-it and the bidding game approaches to estimating willingness-to-pay in a rural population in West Africa. Soc Sci Med. 2003;56(10):2181-9.

21. Hussen A. Principles of environmental economics. 2nd ed. New York: Routledge; 2005.

22. Jenkins MW, Scott B. Behavioral indicators of household decision-making and demand for sanitation and potential gains from sanitation marketing in Ghana. Soc Sci Med2007;64:2427-42.

23. Kazi Faisal Bin Seraj. Willingness to pay for improved sanitation services and its implication on demand responsive approach of BRAC water, sanitation and hygiene programme. Dhaka: Dhaka Research and Evaluation Division; 2008.

24. Ministry of Agriculture and Rural Development: National program on water and sanitation 2010-2015. Hanoi: Ministry of Agriculture and Rural Development; 2010. 
25. Pat S. Health, poverty, and sanitation to feature highly in world summit. Br Med J. 2002;325(7361):405.

26. Jenkins MW, Curtis V. Achieving the 'good life': why some people want latrines in rural Benin. Soc Sci Med. 2005;61(11): 2446-59.

27. Morrison GC, Gyldmark M. Appraising the use of contingent valuation. Health Econ. 1992;1(4):233-43.

28. Diener A, O'Brien B, Gafni A. Health care contingent valuation studies: a review and classification of the literature. Health Econ. 1998;7(4):313-26.
29. Gunatilake H, Yang JC, Pattanayak S, Van den Berg C. Willingness-to-pay and design of water supply and sanitation projects:a case study. Manila: Asian Development Bank; 2006.

30. Griffin C, Briscoe J, Singh B, Ramasubban R, Bhatia R. Contingent valuation and actual behavior: predicting connections to new water systems in the state of Kerala, India. World Bank Econ Rev. 1995;9(3):373-93. 